\title{
LITERACY AND ART: COLLAGE FOR PRE-SERVICE TEACHERS
}

\author{
Alice J. Feret, EdD \\ Associate Professor of Reading, College of Education \\ East Carolina University \\ Judith J. Smith, EdD \\ Assistant Professor of Elementary Education, College of Education \\ East Carolina University
}

\begin{abstract}
Art educators have a unique opportunity to develop and strengthen a crosscurricular foundation in literacy through art education. Enrolled in a content area reading course, pre-service teachers in art education at one, large southeastern university discovered that using language skills as a lens sharpened their observations of student performance in art classes at the elementary and high school levels.
\end{abstract}

The inclusion of brief lessons featuring listening, reading, speaking, or writing strategies revealed unanticipated academic needs, which impacted classroom performance and artistic development. This increased awareness deepened preservice teachers' understanding of young students as learners and allowed the preservice teachers to adjust their lesson planning and classroom management skills.

The pre-service teachers were more confident in their practice as they witnessed

the results of their efforts in terms of students' improved levels of artistic achievements.

Educators across all disciplines are findings ways to develop and strengthen a cross-curricular foundation in literacy. Whether in fine arts, health, mathematics, physical education, science, or social studies, teachers assist students in gaining knowledge of texts they encounter in accordance with the Australian Department of Education's Literacy Policy (1997), which states:

Literacy...includes the cultural knowledge which enables a speaker, writer or reader to recognize and use language appropriate to different social situations. (Students) learn about the power of language to convey explicit and implicit meanings and layers of meaning, and they develop the capacity to discuss and analyze texts and language. (p. 9)

Students look critically at multimedia, performance, spoken, visual, and written texts that question and challenge attitudes, beliefs, and values to make meaning from the array of musical, multimedia, sound, visual imagery, and virtual worlds that confront everyone. Mindful of each challenge for seasoned teachers, the researchers in this study focused on pre-service teachers, as they investigated the question: How should literacy pervade curricula specifically in art education?

The concept of integrating language arts objectives with specialty subject areas like art began to appear in the literature in the late 1990's, as an outgrowth of the National Standards for Arts Education, (1994). That document identified the knowledge and skills basic to competencies in the arts and highlighted a "positive correlation between a substantive education in the arts and student achievement in other subjects and on

Students look critically at multimedia, performance, spoken, visual, and written texts that question and challenge attitudes, beliefs, and values to make meaning from the array of musical, multimedia, sound, visual imagery, and virtual worlds that confront everyone. 
standardized tests" (p. 7). With the Goals 2000: Educate America Act (1994) federal mandate, art education attained legitimacy as a core subject, emerging from the sideline to which American education regularly relegates the fine arts during cyclical debates over public funding.

During this same decade, a stream of various "report cards" [from the National Center for Educational Statistics, the National Reading Panel et al (Reading Today, p. 4)] detailed the nation's literacy levels; and legislation underscored the obligation of public schools to raise the literacy level of all students $(N C L B, 2002)$. "Reading Across the Curriculum," an inter-disciplinary staple of literacy learning in progressive school districts nationwide, suddenly became the norm.

Public school art educators saw this as a surprising reversal. Long accustomed to collaborating with content area teachers in order to support and justify the continued existence of art in school curricula, educators now faced a shift from integrating the arts into educational programming to reinforcing basic language arts skills within art classes.

Stewart and O'Brien (1989) reported that most secondary teachers felt not only unwilling but also inadequately prepared to teach communication skills ( $p$. 397); likewise, public school faculty and state departments of education grappled with implementation of these updated standards for the new century. Similarly, university teacher-preparation programs sought to align their courses of study with a cross-curricular literacy focus.

The insertion of literacy objectives into graduation requirements for teacher preparation programs affected education majors in all content areas. The current study investigated how pre-service art teachers learned to blend literacy lessons with art foci for public school students at one NCATE (North Carolina Association of Teacher Educators) approved college of education. In particular, the study examined the outcomes of integrating three consecutive lessons in listening, reading, writing or speaking on pre-service art teachers in elementary and high school placements.

\section{Why should literacy pervade curricula?}

According to Hladczuk and Eller (1992), literacy is "the vehicle of education, the means through which ideas, information, knowledge and wisdom are expressed and exchanged" (p. ix). Literate individuals possess the capacity to function fully in society: to make reasoned choices, to acquire meaningful employment, to participate in civic affairs.

Reading and writing represent literacy in its most familiar forms: the process of scanning letters or symbols to gain meaning and the recording of thought in somewhat permanent form. Listening and speaking is the second pair of language skills that identify a literate people. Speech is a mode of oral communication, expressing thought; listening assumes a thoughtful consideration of sound, whether verbal or

\section{Literate individuals possess the capacity to function fully in society: to make reasoned choices, to acquire meaningful employment, to participate in civic affairs.} artistic. Listening is also an attribute of student conduct, the core of classroom management plans. In tandem, these four literacy processes shape cognition.

However, Ryan (1992) stated, "[t]he most fundamental educational skill is not reading, but thinking. Reading is important precisely because it provides food for thought in nourishing doses" (p. xii). Since democratic government depends on informed participation of its citizenry, reading in America has long been "our common concern and collective responsibility" (Ryan, 1992, p. ix). National legislation now in place (U.S. Department of Education, 2002) offers federal grant 
money to states, providing they screen children at risk for reading failure and comply with strictly defined remediation and assessment measures. School districts in participating states have required the help of all faculty members in concerted efforts to raise standardized test scores by teaching reading and writing across all disciplines.

The current United States educational emphasis on the fields of science, technology, engineering, and math (STEM, 2008) offers great potential for maximizing not only students' understanding of specific content-related ideas and concepts but also their engagement as readers and writers (Atkinson et al., 2009). Since the same skills and strategies are fundamental to reading comprehension regardless of the subject area, teachers can explicitly model how to activate background knowledge, clarify, question, predict what will happen, and summarize information within these content areas.

The National Council of Teachers of Mathematics (NCTM) emphasizes "the important role of communication in helping children construct understandings of mathematical concepts and develop connections between their informal knowledge and the abstract symbolism of mathematical concepts" (Hunsader, 2004, p. 618). Literature can be used to engage learners in meaningful conversations and investigations in mathematics (Hunsader, 2004), thus providing a means for mathematics and language skills to develop simultaneously (Hellwig et al., 2000). Weiland's study of children's thoughts about division problems (as cited in Sanders, 1996) suggests that verbal responses can guide differentiated instruction.

Science and physical education require

Since the same skills and strategies are fundamental to reading comprehension regardless of the subject area, teachers can explicitly model how to activate background knowledge, clarify, question, predict what will happen, and summarize information within these content areas. oral language skills such as "active listening, following oral directions, and stating needs and discussing issues" (Ballinger \& Deener, 2006). Written skills, such as assessing curricular goals, keeping fitness journals or reviewing tasks completed cooperatively, highlight the role of students in monitoring personal growth. Oliver \& Garrison (1996) also noted the importance of speaking and writing in dance classes, as students describe the impact of physical movement on their bodies, thus increasing self-awareness.

Music teachers and researchers have found ways to make the language literacy-music connection possible, because several musical skills parallel language literacy skills. Hansen (2009) and Pearce (2000) maintain that writing about music expands students' musical vocabulary and their "conceptual understanding...of the art form" (Hansen, p. 28). Liperote (2006) combines speaking and listening in her band classes by stressing the singing of rote songs. Peisch (1995) describes an inquiry approach to the musical ensemble that encompasses all four literacy skills. Others emphasize how learning to read print and to read music are complementary skill sets, because both utilize text and symbols (Darrow, 2008; Hansen \& Bernstorf, 2002; Locklear, 2002).

Health literacy, which includes oral and written comprehension of instruction and medical terms, depends upon both expressive (speaking, writing) and reflective (listening, reading) literacy skills. Mantone (2005) claims that support for making "appropriate health decisions" could begin in pre-kindergarten ( $p .30$ ). Bolton (2005) maintains that written narrative in medical classes paired with literature "offers dynamic ethical issues with which to grapple" (p. 171); this practice could transfer easily to health or contemporary history classes in public schools. 


\section{How does literacy instruction impact art education?}

Art educators and literacy educators acknowledge an overall interconnectedness that reframes teaching of both disciplines, but the details have provoked discussion in the research community. Some researchers have scrutinized art education in its entirety. Educational theorist Eisner (1976, 1982, 1995) repeatedly maintained that the arts should be taught for the purpose of developing reflective, aesthetic and emotional dispositions. Reisberg, Brander, \& Gruenewald (2006) advocated for a social reconstructionist arts education, which would include an indefinable change in the content, instructional methods, and organization of curriculum. Kalin \& Kind (2006) restated the value of pre-service art teachers working directly with children in order to identify students' concept of art learning in order to maximize their teaching. Simanski (2008) justified art education by identifying its impact on the achievement gap: "In the art room any child can succeed..." (p. 12).

Some, like Baldacchino (2008), see a divide between learning and education: "If art conforms, it has no use to learning. If it becomes synonymous with learning, then it is not art anymore" ( $p .242$ ). He boldly suggested that "The teaching and learning of art is trapped between the assumptions of process and product...knowledge is a matter to be discovered but never determined, and where a fixed ground is transformed into a wide horizon" (p. 241).

Lorimer (2009) supported Baldacchino's premise regarding the "discovery process" in art but used the visual scanning concept as a strategy to support interdisciplinary learning. He explained:

Visual scanning can be implemented in any classroom at any

level. To begin teachers select an art print or artifact for viewing.

After one minute of quiet observation, students begin responding

to and posing questions that prompt deeper thinking:

(a) What else do you see?

(b) How do you know?

(c) What evidence may support that?

In this way all students are allowed to share what they see and

think. (p. 11)

Since all children experience visual and graphic development as they grow, effective visual perception seems fundamental to learning at any age in any field or content area (Cornia, 1983).

As expressive modes, visual arts and language arts both share a common focus on communication: listening, reading, speaking, and writing. Stephens \& Walkup (2000) identified higher-order thinking skills and the five-step writing process as vital components of the framework for deeper exploration of art.

Simanski (2008) noted that "...Images and examples can take the place of words," but he readily acknowledged verbal discourse as a vital link in art education when he continued: "Learning takes place when students look at, discuss and make art" (p. 12). Cornia (1983) maintained that young children begin to express uniqueness with artistic efforts (such as scribbling) that satisfy the need to communicate both ideas and feelings, but they soon learn ways to talk and write about art. Vacca \& Vacca (2002) reported that students, in one high school art class, kept a sketchbook to guide their thoughts and record emotional responses to what they were seeing and studying. Such a continuous record of personal responses to art is not only a versatile writing-to-learn strategy, but also a key element in building the reflective behaviors that Eisner espoused.

Hurwitz \& Day (2007) suggested that the actual exposure to visual images provides issues and topics that motivate children to speak and write, to think and learn within the framework of art. Using visual concepts and vocabulary in 
discussing art, art criticism moves children beyond the mere descriptive use of language to formal analysis and interpretation of meaning in art.

lyengar (2008) discovered behavior patterns associated with literary reading that impact the fine arts. He found that adults who read are three to four times as likely as nonreaders to visit art museums and attend plays. He stated, "By stressing the need to read widely and to read well, arts educators and cultural policymakers will cultivate the audiences and artists necessary to sustain creativity in the United States" workforce" (p. 25).

Literacy subtly permeates art curricula. Eisner (1998) summarized "...Perhaps, the largest lesson that the arts in education can teach [is] the lesson that life itself can be led as a work of art..." (p. 56).

\section{Description of the Study}

The study involved eight pre-service teachers ( 6 females, 2 males) in art education, who were enrolled in a required content area reading course while student teaching during the last semester of their senior year at a large, southeastern university. The pre-service teachers had placements at the level of their choice: three were at elementary schools and five at high schools (Table 1 ). Each school was located within a mostly rural area of varied socioeconomic level and racially diverse towns that surrounded the university community.

Midway through the semester, after background in instructional reading levels, comprehension strategies, and the readability of school-issued texts, the pre-service teachers were asked to observe an art class of their choice and to identify one language-related issue that seemed to interfere with optimal teaching and learning in elementary or high school art classes. With the supervising teacher's approval, each pre-service teacher then constructed and implemented three consecutive lessons to address the problematic area. Lesson format was a personal choice (entire period, mini-lesson, small group or whole class), but a focus on one literacy skill (listening, reading, speaking, writing) as the method of instruction was a requirement.

The following examples illustrate lessons pre-service teachers created using specific literacy skills as a focus. Listening lessons for high school art class combined listening and following directions in order to understand and apply the two-point perspectives in an art work. Students listened to the teacher explain how to create imaginary environments containing buildings, landscapes for horizon lines and to incorporate organic still-life forms. In a photography class, students listened to enhance note-taking skills. One pre-service teacher stated:

Photography is very hands-on. There is also an endless amount of information about the processes, chemicals and history of photography. Students will not just pick up the photography book and read it for the fun of it. To practice note-taking skills about important information in photography, I will incorporate open note quizzes into the curriculum. Students will have to learn how to take thorough notes, pull important points out of the lecture and keep track of their notes.

Listening lessons in art at the elementary level included students listening to directions for making an accordion book with warm and cool colors. Students also focused on listening to complete a lesson on Van Gogh's painting, "Starry Night."

Reading lessons in art classes helped students interpret, evaluate, and apply information. In the course Renaissance Art and Perspective Drawing, a focus on reading comprehension provided students with opportunities to draw inferences and analyze data. A lesson using Matisse cutouts demonstrated how telling a story 
in visual terms could support reading comprehension. Reading medieval art literature supplied context for a lesson on calligraphy and illuminated manuscripts.

Writing lessons included a research paper on a sculptor. A second lesson focused on using quotes from a sculptor to explore the world of art. Students wrote weekly in a sketchbook by journaling, sketching, collecting images, and writing poems and/or thoughts. This pre-service teacher asked students to respond to the following questions about the sculptor's quotations: (a) What do you think this quotation is saying? (b) What do you think about the quotation and why? (c) Can this quotation relate to your life? The purpose of the assignment was to have students realize that artists can combine both reflective and critical writing with their artwork.

Speaking lessons helped students express their interpretation of art. Because growth comes from discussing art, as well as expressing oneself through art, the students learned to speak about what makes some art more successful and why.

After each lesson, participants recorded in a research notebook what worked, what did not work, and what they would do differently next time. Upon completion of the third consecutive lesson, pre-service teachers reflected on the project by responding to six questions designed to invite analysis, synthesis, and comments. The questions were:

(a) Did your lessons go according to plan?

(b) What did you learn about your students through these lessons?

(c) Did you learn something about your students that you might not have known otherwise?

(d) Did the lessons OR new learning make a difference in how you planned for instruction?

(e) How will you transfer this awareness to your own professional practice?

(f) Any random comments?

At the conclusion of the project, pre-service teachers met near campus with a guest art educator in one of two, small peer groups to present five-minute summaries of their projects. One at a time, they identified the literacy skill they had selected, described one lesson they had taught, and verbally shared what they had learned. After each summary, the guest art educators evaluated the presentations and assigned a grade to each project.

\section{Methodology for Analysis}

The instructor, who was also one of the researchers for this study, read the reflective summaries and circled quotations, key phrases in response to the questions, and any additional commentary. Utilizing the four literacy skills (listening, speaking, reading, and writing) and the study's basic framework of new understandings in regard to self-awareness and insights, she began by sorting data into distributions by school placement and art class.

Next, the researcher listed the pre-service teachers' responses to questions. A total of 105 responses to questions two through five were received. Six participants shared random comments in response to question six.

The researcher refined categories by highlighting and grouping the responses according to the chosen literacy skill. Although each question stimulated a direct response from many participants, the questions provoked reflection from some. The researcher created subgroups and used analytic induction to explore the data and denote contrasts in responses. 
In order to prevent bias, a colleague with no connection to the course or to art education students also reviewed the distributions and reanalyzed the data. She provided oral and written comments related to the data to the researchers in order to coalesce the results of the study.

\section{Results}

Table 1 shows that two of three pre-service teachers at elementary schools chose to focus on listening skills, and three of six at high schools. By contrast, no elementary art pre-service teachers focused on reading, while reading concerned only one high school placement. One teacher at the elementary school level selected speaking as a focus, and one at the high school level selected writing as a focus. Overall, both elementary and high school pre-service teachers selected "listening" as a literacy focus in art class.

Table 1: Distribution of literacy skills selected for lesson focus by school placement

\begin{tabular}{|c|c|c|c|}
\hline Literacy Skill & Elementary School & High School & Total \\
\hline Listening & 2 & 3 & 5 \\
\hline Reading & 0 & 1 & 1 \\
\hline Speaking & 1 & 0 & 1 \\
\hline Writing & 0 & 1 & 1 \\
\hline Total & 3 & 5 & 8 \\
\hline
\end{tabular}

In response to the introductory question ("Did your lessons go according to plan?"), pre-service teachers indicated that in teaching their first and second lessons they learned much about their students but the lessons did not always go as planned. While teaching the third lesson, pre-service teachers noted that their lessons were successful.

Tables 2-5 display pre-service teachers' responses to four questions designed to help them analyze and synthesize the results of their experiences with literacy lessons in art curricula. Tallies varied in number because some participants offered multiple comments, while others declined to comment.

Many learned to identify which students understood the material, who was struggling, and why; see Table 2. Pre-service teachers gained new understandings about their students, self-awareness of their teaching, and insight regarding literacy and art. They found that students' personal values are reflected in their application and understanding of art.

Those who had focused on listening skills reported that students produced a good product when they listen. While one complained, "Listening is the problem area in art education," another observed that "Teachers can enhance the students' abilities to assimilate information creatively." One stated, "Students learn in different ways: some visually and some aurally"; and another conceded, "Elementary students cannot listen attentively for a long time."

One pre-service teacher committed to reading skills quickly recognized that "Many students at the high school level answer questions but cannot back up their answers." Students enjoyed making predictions and evaluative judgments, yet they were completely reticent when asked to critique their own art products or connect what they believed with current reality.

The pre-service teacher who selected speaking as a focus shared that "Students are eager to learn and express thoughts about art, yet they struggle with 
the notion of meaning despite explicit instruction." She also considered whether "Some art concepts are too difficult for second graders."

Table 2: What did you learn about your students through these lessons?

\begin{tabular}{|c|c|c|c|c|c|}
\hline New Understandings & Listening & Reading & Speaking & Writing & Total \\
\hline $\begin{array}{l}\text { Students answer questions } \\
\text { but cannot back up their } \\
\text { answers. }\end{array}$ & & 1 & & 1 & 2 \\
\hline $\begin{array}{l}\text { Students are eager to learn } \\
\text { and express thoughts about } \\
\text { art. }\end{array}$ & & & & 1 & 1 \\
\hline $\begin{array}{l}\text { Students have difficulty } \\
\text { critiquing their own art } \\
\text { work. }\end{array}$ & & & & 1 & 1 \\
\hline $\begin{array}{l}\text { Students listen when taking } \\
\text { notes. }\end{array}$ & 1 & & & & 1 \\
\hline $\begin{array}{l}\text { Students produce an } \\
\text { excellent product when they } \\
\text { listen. }\end{array}$ & 2 & 1 & & & 3 \\
\hline $\begin{array}{l}\text { Students struggle with } \\
\text { meaning despite explicit } \\
\text { instruction. }\end{array}$ & 1 & & 1 & & 2 \\
\hline \multicolumn{6}{|c|}{ Self-awareness } \\
\hline $\begin{array}{l}\text { Students learn in different } \\
\text { ways: some visually and } \\
\text { some aurally. }\end{array}$ & 1 & & & & 1 \\
\hline $\begin{array}{l}\text { Teachers can enhance the } \\
\text { students' abilities to } \\
\text { assimilate information } \\
\text { creatively. }\end{array}$ & 1 & & & & 1 \\
\hline $\begin{array}{l}\text { Teachers can motivate } \\
\text { students to listen by making } \\
\text { an assignment. }\end{array}$ & 1 & & & & 1 \\
\hline \multicolumn{6}{|c|}{ Insights } \\
\hline $\begin{array}{l}\text { Clear plans/demonstrations } \\
\text { produce improved student } \\
\text { response. }\end{array}$ & 1 & 1 & & & 2 \\
\hline $\begin{array}{l}\text { Students are more attentive } \\
\text { during lessons which interest } \\
\text { them. }\end{array}$ & 1 & & & & 1 \\
\hline Total & 9 & 3 & 1 & 3 & 16 \\
\hline
\end{tabular}

The pre-service teacher who selected writing skills agreed with the reading-focus summaries that "Students answer questions but cannot back up their answers." She also cited students' "difficulty critiquing their own art work" as a core issue.

Table 3 indicates what pre-service teachers learned about students through the delivery of literacy lessons. They observed different degrees of student engagement throughout the lessons and gradually recognized in students a mix of developmental and instructional needs. 
Table 3: Did you learn something about your students that you might not have known otherwise?

\begin{tabular}{|c|c|c|c|c|c|}
\hline New Understandings & Listening & Reading & Speaking & Writing & Total \\
\hline $\begin{array}{l}\text { Students express their } \\
\text { opinions in different ways. }\end{array}$ & & & & 1 & 1 \\
\hline $\begin{array}{l}\text { Students have problems } \\
\text { listening to a set of multiple } \\
\text { steps in a project. }\end{array}$ & 1 & & & & 1 \\
\hline $\begin{array}{l}\text { Students have a gap in } \\
\text { understanding art concepts } \\
\text { of linear perspective. }\end{array}$ & & 1 & & & 1 \\
\hline $\begin{array}{l}\text { Students have difficulty } \\
\text { expressing their opinions in } \\
\text { written form and in } \\
\text { explaining steps of projects. }\end{array}$ & & & & 1 & 1 \\
\hline $\begin{array}{l}\text { Students have problems } \\
\text { writing in an organized } \\
\text { format. }\end{array}$ & & & & 1 & 1 \\
\hline $\begin{array}{l}\text { Students need a more } \\
\text { authoritarian approach from } \\
\text { me. }\end{array}$ & 1 & & & & 1 \\
\hline $\begin{array}{l}\text { Students need to hear } \\
\text { directions repeated. }\end{array}$ & 1 & & & & 1 \\
\hline $\begin{array}{l}\text { Students need varied } \\
\text { instructional strategies. }\end{array}$ & & 2 & & 1 & 3 \\
\hline Students want consistency. & 1 & & & & 1 \\
\hline \multicolumn{6}{|c|}{ Self-awareness } \\
\hline $\begin{array}{l}\text { Awareness of why students } \\
\text { don't listen is important. }\end{array}$ & 1 & & & & 1 \\
\hline $\begin{array}{l}\text { Clear plans/demonstrations } \\
\text { produce improved student } \\
\text { response. }\end{array}$ & 2 & & & & 2 \\
\hline \multicolumn{6}{|c|}{ Insights } \\
\hline $\begin{array}{l}\text { Students listen well and pay } \\
\text { attention when the teacher } \\
\text { reads aloud. }\end{array}$ & 1 & 1 & & & 2 \\
\hline $\begin{array}{l}\text { Students need constant } \\
\text { reinforcement. }\end{array}$ & & & 1 & & 1 \\
\hline Total & 8 & 4 & 1 & 4 & 17 \\
\hline
\end{tabular}

Table 4 details how knowledge gained might influence instruction. With documented awareness of students' specific needs, pre-service teachers planned differently. They actively modified their teaching style by strengthening the procedural elements of their instructional planning to match students' Zone of Proximal Development (Vygotsky, 1934/1978). They adjusted their style, methodology, and/or course content. 
Table 4: Did the lessons OR new learning make a difference in how you planned for instruction?

\begin{tabular}{|c|c|c|c|c|c|}
\hline New Understanding & Listening & Reading & Speaking & Writing & Total \\
\hline $\begin{array}{l}\text { Students' attention needs to } \\
\text { be on the teacher "All eyes } \\
\text { on me." }\end{array}$ & 1 & & & & 1 \\
\hline $\begin{array}{l}\text { Students have difficulty } \\
\text { expressing thoughts in } \\
\text { words instead of drawings. }\end{array}$ & & & & 1 & 1 \\
\hline $\begin{array}{l}\text { Students should take notes } \\
\text { during lecture to help their } \\
\text { understanding. }\end{array}$ & 1 & & & & 1 \\
\hline $\begin{array}{l}\text { Students should categorize } \\
\text { to organize their notes. }\end{array}$ & 1 & & & & 1 \\
\hline $\begin{array}{l}\text { Students need constant } \\
\text { practice. }\end{array}$ & & & & 1 & 1 \\
\hline $\begin{array}{l}\text { Students used vocabulary } \\
\text { sheets to understand } \\
\text { concepts in two- and three- } \\
\text { dimensional art concepts. }\end{array}$ & & 2 & & & 2 \\
\hline \multicolumn{6}{|c|}{ Self-awareness } \\
\hline $\begin{array}{l}\text { List steps for the lesson on } \\
\text { the board. }\end{array}$ & 1 & & & & 1 \\
\hline Make directions explicit. & 1 & & 1 & & 2 \\
\hline $\begin{array}{l}\text { Organize the lecture into } \\
\text { steps. }\end{array}$ & 1 & & & & 1 \\
\hline $\begin{array}{l}\text { Provide an anticipation } \\
\text { guide. }\end{array}$ & & 2 & & 2 & 4 \\
\hline $\begin{array}{l}\text { Push students to be creative } \\
\text { and express their thoughts } \\
\text { in words. }\end{array}$ & & & & 1 & 1 \\
\hline $\begin{array}{l}\text { Rehearse the material to } \\
\text { address potential pitfalls. }\end{array}$ & & 2 & & 1 & 3 \\
\hline $\begin{array}{l}\text { Talk with students about } \\
\text { their opinions, research } \\
\text { problems. }\end{array}$ & & & & 1 & 1 \\
\hline $\begin{array}{l}\text { Teach a multiple step } \\
\text { project in different ways. }\end{array}$ & 1 & & & & 1 \\
\hline \multicolumn{6}{|c|}{ Insights } \\
\hline $\begin{array}{l}\text { Timing is vital to the success } \\
\text { of the lesson. }\end{array}$ & 1 & 1 & 1 & & 3 \\
\hline $\begin{array}{l}\text { Struggling readers respond } \\
\text { to small units of instruction. }\end{array}$ & 1 & & & & 1 \\
\hline Total & 9 & 7 & 2 & 7 & 25 \\
\hline
\end{tabular}

Pre-service teachers noted, "Timing is vital to the success of the lesson"; and "Struggling readers respond to small units of instruction." Additional comments included: "Students need constant practice," "categorizing assists the students in organizing their notes," and "students need visual examples of projects."

Table 5 lists pre-service teachers' responses to how this expanded understanding of student development might shape their future practice. Over half of the group pragmatically listed nine effective instructional strategies to use in their classrooms.

The creation of more developmentally appropriate instructional and delivery techniques for an integrated curriculum, as noted in Tables 4 and 5, paralleled an increase in both personal and professional growth for some pre-service teachers. As a result of multiple opportunities for written reflection, several study 
participants identified instructional concepts that seemed to promote student learning more than others. They also recognized personal qualities that could enhance their interactions with students, as evidenced by an increased number of comments categorized as "self-awareness" and "insights" in Tables 4-5. The six preservice teachers, who responded to Question \#6, any random comments? (about the project, which did not pertain directly to the questions framing the study), expressed similar insights and growth in self-awareness.

Table 5: How will you transfer this awareness to your own professional practice?

\begin{tabular}{|c|c|c|c|c|c|}
\hline New Understandings & Listening & Reading & Speaking & Writing & Total \\
\hline Critique works of art. & 1 & 1 & & 1 & 3 \\
\hline $\begin{array}{l}\text { Establish a classroom } \\
\text { climate that promotes } \\
\text { creativity and self } \\
\text { expression. }\end{array}$ & 1 & 1 & & 1 & 3 \\
\hline $\begin{array}{l}\text { Observe, speak to, and } \\
\text { evaluate the students' } \\
\text { ability to understand and } \\
\text { apply art concepts being } \\
\text { taught. }\end{array}$ & 1 & & & & 1 \\
\hline $\begin{array}{l}\text { Use writing to provide a } \\
\text { purpose in learning about } \\
\text { art. }\end{array}$ & & & & 2 & 2 \\
\hline $\begin{array}{l}\text { Utilize the vast array of } \\
\text { resources directed toward } \\
\text { helping students with } \\
\text { reading difficulties. }\end{array}$ & 1 & & & & 1 \\
\hline \multicolumn{6}{|c|}{ Self-awareness } \\
\hline $\begin{array}{l}\text { Be aware of how students } \\
\text { learn. }\end{array}$ & 1 & & 1 & & 2 \\
\hline $\begin{array}{l}\text { Develop appreciation for } \\
\text { the arts. }\end{array}$ & 1 & 1 & 2 & & 4 \\
\hline Review every day. & 1 & & & & 1 \\
\hline Scaffold student learning. & & 1 & & & 1 \\
\hline $\begin{array}{l}\text { Teach art projects in } \\
\text { different ways. }\end{array}$ & 1 & & & & 1 \\
\hline $\begin{array}{l}\text { Teach how art is applied to } \\
\text { everyday life. }\end{array}$ & 1 & & 1 & 1 & 3 \\
\hline \multicolumn{6}{|c|}{ Insights } \\
\hline $\begin{array}{l}\text { Awareness of problems } \\
\text { leads to easier solutions. }\end{array}$ & 1 & & & & 1 \\
\hline $\begin{array}{l}\text { Frequency of (listening, } \\
\text { reading) exercise develops } \\
\text { understanding of concept. }\end{array}$ & 1 & 1 & & & 2 \\
\hline $\begin{array}{l}\text { Incorporating reading and } \\
\text { writing in the art classroom } \\
\text { helps students become } \\
\text { comfortable expressing } \\
\text { themselves through art. }\end{array}$ & 1 & & & & 1 \\
\hline $\begin{array}{l}\text { Teaching students that art } \\
\text { projects do not have to } \\
\text { look perfect promotes } \\
\text { creativity. }\end{array}$ & 2 & & & & 2 \\
\hline Total & 14 & 5 & 4 & 5 & 28 \\
\hline
\end{tabular}


Table 6 summarizes the instructional methods public school students need in order to explore artistic concepts successfully. Pre-service teachers synthesized these methods after teaching the requisite three classes noted above.

Table 6: Distribution of art students' instructional needs, as observed by pre-service art teachers

\begin{tabular}{|l|c|c|c|c|c|}
\hline Instructional Needs & Listening & Reading & Speaking & Writing & Total \\
\hline $\begin{array}{l}\text { Background } \\
\text { knowledge in art } \\
\text { history }\end{array}$ & 1 & 1 & 1 & 1 & 2 \\
\hline Clear demonstrations & 1 & 1 & 1 & 1 & 2 \\
\hline $\begin{array}{l}\text { Critiques of art } \\
\text { projects }\end{array}$ & 2 & & & 1 & 3 \\
\hline $\begin{array}{l}\text { Deliberate, thorough } \\
\text { planning }\end{array}$ & 1 & 1 & & 1 & 3 \\
\hline $\begin{array}{l}\text { Directions repeated, } \\
\text { rephrased }\end{array}$ & 1 & 1 & 1 & 3 \\
\hline $\begin{array}{l}\text { Problem } \\
\text { solving/Student } \\
\text { assessment }\end{array}$ & 1 & 1 & & & 2 \\
\hline $\begin{array}{l}\text { High interest } \\
\text { materials }\end{array}$ & 1 & 1 & & & 2 \\
\hline $\begin{array}{l}\text { Scaffolded/reinforced } \\
\text { instruction }\end{array}$ & 1 & 8 & 3 & 6 & 25 \\
\hline $\begin{array}{l}\text { Short lessons (15 } \\
\text { minutes) }\end{array}$ & & & & & 2 \\
\hline $\begin{array}{l}\text { Varied instructional } \\
\text { strategies }\end{array}$ & 1 & & & \\
\hline Visual approaches & 1 & & & \\
\hline Total & & 1 & & \\
\hline
\end{tabular}

\section{Discussion}

The results of this study indicate that pre-service teachers gained new knowledge about their students and about themselves as practitioners. The literacy lessons provided a lens through which they could sharpen their observations and appraise student behaviors. The actual organizing and sequencing of objectives in lesson plans appeared to spur pre-service teachers to consider appropriate instructional goals for all learners and move students systematically forward.

Pre-service teachers began their student teaching experience armed with art skills, knowledge, and pedagogy. Understandably lacking the daily exposure to students, they were unaware of how literacy

The literacy lessons provided a lens through which they could sharpen their observations and appraise student behaviors.

positively affects student dispositions. One pre-service teacher commented, "The class behaved better when I had them read about something. I could hardly believe they would listen so well or pay so much attention to the written word." After reading about the two-point perspectives in art, students found it easier to express themselves and explain their art projects. One pre-service teacher decided,

I will open my students' eyes and show them the endless possibilities of art. I will give the shy, timid student the 
encouragement to show the world her work. I will continue to incorporate reading and writing into my art classroom.

If this is the case, earlier field experiences could familiarize pre-service teachers with the benefits of incorporating literacy instruction within art education to strengthen their students' emotional, social and artistic development across myriad settings: art room, classroom, museum, and studio.

A second result of the study was that pre-service teachers realized that incorporating literacy instruction in art class enhanced creativity and the quality of art projects. One pre-service teacher realized, "I have the opportunity to enhance a student's abilities to assimilate information creatively and apply it to the discipline of art." Although "listening is the problem area in art" education, students became aware that "to make their projects better, they need to listen to the lesson well." Another pre-service teacher commented, "Students took pride in remembering lines from the book. It seemed to push them to picture what was being said and that is great for visual arts."

Untutored in literacy methods, pre-service teachers were initially uncomfortable linking a literacy project to art. Yet, through implementation of the literacy lessons, they discovered numerous instructional strategies to incorporate literacy in art class. One teacher listed the steps for a sculpture project on the board, told the student the steps and had them take notes. Another noted:

I need to make the directions explicit. The more I review the project and tell students the steps, the more they understand. I cannot just tell the directions to a multiple step project, I have to teach them in different ways. I will write the steps on the board, give a visual example and a handout, and let students read the steps for themselves.

A different pre-service teacher said she would provide an anticipation guide for her students, and another mentioned she would provide tangible manipulatives to connect the art concept to concrete objects and examples. Still another revealed that "The worksheet reinforced the vocabulary and took a rather abstract concept and asked students to demonstrate their understanding by drawing."

Integrating multiple literacy strategies, a third result of this study, provided art students with tools to improve the quality and creativity of artwork. Implementing these strategies indirectly supported the development of more expressive artists and thus, facilitated their projects.

A fourth result of the study was that incorporating speaking and writing instruction in art class developed the skills of art criticism. Since art criticism is a very important component of art education, students must be able to speak knowledgeably about artwork. A pre-service teacher said, "I will make it a priority with each grade to always introduce some type of art history and talk about art: how it makes you feel and how it is successful." Another teacher stated, "Talking individually with students about their painting got some really interesting answers and helped them begin to understand important elements of art." Students need to think about the art concept as they are working on a project and understand what makes art successful or unsuccessful.

In writing, pre-service teachers found that "Students need to realize that even in art class, writing can provide a purpose in learning about art." One teacher explained:

Writing in the curriculum is important to incorporate in art courses. Students can use writing in self critiques, and then they will get better at explaining their thoughts and remember certain art processes through written communication.

Another pre-service teacher added that she would have a verbal critique at the end of the lesson so students could practice talking about their artwork and how 
they could make their pieces better. "Students have difficulty critiquing their own work, because they are not sure how to improve the work and to explain it in words," she stated.

Said one pre-service teacher, "My students knew how to get the right answers but could not synthesize the material and arrive at creative responses, which is vital in an art class." Others found, "Students express their opinions in different ways--verbal communication, visual communication, and written expression." This challenged pre-service teachers to differentiate content to match learning styles and capacities.

By including all learning modalities (aural, kinesthetic, visual) and integrating literacy skills, pre-service art teachers realized that they have "increased their overall sense of efficacy. They are less intimidated by my students' problems and more concerned with finding a proactive solution to ensure them success."

Finally, the study revealed that literacy instructional methods can assist art educators in accepting their responsibility "to develop an appreciation for the arts." One pre-service teacher explained that "Establishing a classroom climate that promotes self creativity and expression while balancing the need to constructively critique works of art is of paramount importance." Another stated, "Teaching art is a culmination of a lifelong journey. It provides the opportunity to lead young minds into the exploration of abstract ideas." Two pre-service teachers noted, "All students have a sense of creativity" and "Before making assumptions about my students' low motivation or poor attitude, I will check to see if problems are with the assignment and not linked to problems with reading."

\section{Conclusion}

Current research in art education supports and extends the premise that the quality of art teaching and learning in all contexts is paramount. The National Association for Education in the Arts (2008) "identified and defined research needed for professional growth to support and enrich teaching and learning in art education, establish new communities of research, and inform advocacy and policy development" (para. 2). Three main topics of research were: (a) student learning, (b) teaching, and (c) curriculum with student learning and teaching practices of greatest concern.

This study revealed that literacy skills are integral elements of the elementary and secondary art classroom that impact artistic development on many levels. Smith (2005) noted that educators know experientially that context matters and makes for educational effectiveness. He cited Uhrmacher (2001), who argued that schools should help children create

Schools should help children create meaning from experience and that education devoted to meaning-making and the imagination demand a curriculum that fosters multiple literacies not only for students but teachers as well. meaning from experience and that education devoted to meaning-making and the imagination demand a curriculum that fosters multiple literacies not only for students but teachers as well.

Recent research in content area literacy reaffirms the role of all teachers in empowering students to become independent learners (Alvermann, Phelps \& Ridgeway, 2007; Vacca \& Vacca, 2002). Students' ability to listen, read, speak, and write well determines the level of that independence and their overall success in school. Ballinger and Deeney (2006) strongly suggested that all teachers must "capitalize on literacy teaching and learning in every environment possible" so as not to "leave many children ill-prepared for later life" (p. 19). 
Art-teacher educators, who collaborate with pre-service teachers in planning activities tailored to learner needs and preferences in public schools, demonstrate invaluable support for curricula that respect cultural, economic, and linguistic diversity in the classroom. Art-teacher advocates provide pre-service teachers with multiple opportunities for classroom experience and promote the inclusion of strategies that affirm child and adolescent development.

Emphasizing literacy instruction within art curricula can further enrich art teacher preparation and personalize instruction for public school students. By including numerous experiences in practica and clinical teaching opportunities early during their university coursework, pre-service teachers can readily integrate literacy within the art curriculum. Companion studies to determine precisely how best to link theoretical knowledge with public school's formal curriculum seem necessary.

While researchers debate the shape of reform in art teacher preparation programs (Bain, 2009; Kalin \& Kind, 2006; Lorimer, 2009; NAEA, 2008; Reilly, 2009), pre-service teachers are transitioning from course-based knowledge to fieldtested experiences to public school positions every semester. With professional encouragement, pre-service teachers can definitely blend literacy skills with art and gain instructional and professional strength, as they passionately nurture their students' artistic gifts.

\section{References}

Alvermann, D.E., Phelps, S.F. \& Ridgeway, V.G. (2007). Content area reading and literacy: Succeeding in today's diverse classrooms. Boston: Pearson Education.

Atkinson, T.S., Matusevich, M.N. \& Huber, L. (2009). Making science trade book choices for elementary classrooms. Reading Teacher, 62(6), 484-497.

Bain, K. (2009). What the best college teachers do: Implications for teaching art education methods courses for elementary majors. Studies in Art Education,50(2), 205208.

Baldacchino, J. (2008). The praxis of art's deschooled practice.

International Journal of Art \& Design Education, 27(3), 241-250.

Ballinger, D.A. \& Deeney, T.A. (2006). Physical educators as teachers of literacy. Journal of Physical Education, Recreation \& Dance, 77(5), 18-23.

Bolton, G. (2005). Medicine and literature: Writing and reading.
Journal of Evaluation in Clinical Practice, 11(2), 171-179.

Consortium of National Arts

Educations Associations. (1994). National standards for arts education. Reston, VA: MENC.

Cornia, I.E. (1983). Art is elementary: Teaching visual thinking through art concepts. Layton, Utah: G.M. Smith.

Darrow, A. (2008). Music and literacy. General Music Today, 21, 32-34.

Department of Education, Tasmania, School Education Division. (2007). English learning area critical literacy. Retrieved May, 2008, from http://wwwfp.education.tas.gov.au/E nglish/critlit.htm

Eisner, E.W. (1976). The arts, human development and education. Berkeley, CA: McCutchan.

Eisner, E.W. (1982). Cognition and curriculum: A basis for deciding what to teach. New York: Longman. 
Eisner, E.W. (1995). What artistically crafted research can help us understand about schools. Educational Theory, 45(1), 1-6.

Eisner, E.W. (1998). The kind of schools we need: Personal essays. Portsmouth, NH: Heinemann.

Hansen, D. (2009). Writing in the music classroom. Teaching Music, 16 , 28-30.

Hellwig, S., Monroe, E.E., \& Jacobs, J.S. (2000). Making informed choices: Selecting children's trade books for mathematics instruction. Teaching Children Mathematics, 7(3), 138-143.

Hladczuk, J. \& Eller, W. (Eds.). (1992). International handbook of reading education. Westport, CT: Greenwood Press.

H.R. 1804-103 ${ }^{\text {rd }}$ Congress. (1994). Goals 2000: Educate America Act. Washington, DC: U.S. Government Printing Office.

Hunsader, P. (2004). Mathematics trade books: Establishing their value and assessing their quality. The Reading Teacher. 57(7), 618-629.

Hurwitz, A. \& Day, M. (2007). Children and their art methods for the elementary school. Belmont, CA: Thomson Wadsworth.

Iyengar, S. (2008). A federal arts agency at the center of reading research: How we got here. Arts Education Policy Review, 110(1), 2326.

Kalin, N. \& Kind, S. (2006). Invitations to understanding: explorations in the teaching of arts to children. Art Education, 59(3), 36-41.

Locklear, S. (2002). Research-based justification for the highline school district elementary and secondary school music programs. Retrieved February 1, 2009 from http://www. newhorizons.org/strategi es/arts/locklear.htm
Liperote, K.A. (2006). Audiation for beginning instrumentalists. Music Educators Journal, 93, 46-52.

Lorimer, M. (2009). Using interdisciplinary arts education to enhance learning. Principal, 88(3), 812.

Mantone, J. (2005). Reading, writing and relating. Modern Healthcare, 35(32), 30-32.

NAEP says urban districts better in math, lag in reading. (2006,

February/March). Reading Today, 23, 4.

National Art Education Association. (2008). Creating visual arts education research agenda for the $21^{\text {st }}$ century: Encouraging individual and collaborative research. Retrieved April 15, 2009, from http://alumniconnects.com/olc/filelib/ NAEA/Cpages/9002/Library/NAEA\%2 OResearch\% 20Agenda

National Art Education Association. (2008). 2008 NAEA research needs assessment findings, interpretations and implications. Retrieved April 15, 2009 from

http://alumniconnections.com/olc/file lib/NAEA/cpages/9002/Library/Resea rchNeedsSurveyReport.10-20.pdf

Oliver, K. \& Garrison, J. (1996). Reflective writing and kinesthetic listening: The other half of the dance. Journal of Physical Education, Recreation \& Dance. 67(6), 37-40.

Pearce, M. (2000, May 1). A model for improving reading through music study in band and orchestra. Reading Teacher, 53(8), 1-4. Retrieved May 26, 2005, from http://web32.epnet.com/citation.asp

Peisch, S. (1995). Listening to music in the new ninth grade program at Lawrence Academy. Clearing House, 68(6), 347-352. 
Reilly, M. (2009) Opening spaces of possibility: The teacher as bricoleur. Journal of Adolescent \& Adult Literacy, 52(5), 376-384.

Reisberg, M., Brander, B. \& Gruenewald, D. (2006). Your place or mine? Reading, art, place, and culture in multicultural picture books. Teacher Education Quarterly, 33(1), 117-133.

Ryan, J. (1992). Foreword. In J. Hladczuk \& W. Eller (Eds.). International handbook of reading education, ( $p$. ix). Westport, CT: Greenwood Press.

Sanders, S.W. (1996). Children's physical education experiences: Their interpretations can help teachers. Journal of Physical Education, Recreation \& Dance, 67(3), 51-56.

Simanski, C. (2008). Addressing the achievement gap through art. School Arts: The Art Education Magazine for Teacher, 108(4), 12.

Smith, M.K. (2005). Elliot W. Eisner, connoisseurship, criticism and the art of Education. The Encyclopedia of Informal Education. Retrieved from www.infed.org/thinkers/eisner.htm

Stephens, P. \& Walkup, N. (2000). Bridging the curriculum through art interdisciplinary connections.

Glenview, IL: Crystal Productions.
Stewart, R.A. \& O'Brien, D.G. (1989). Resistance to content area reading: $A$ focus on preservice teachers. Journal of Reading, 32, 396-401.

Uhrmacher, P. B. (2001). Elliot Eisner. In J.A. Palmer (ed.) Fifty Modern Thinkers On Education. From Piaget to the Present, London: Routledge.

U.S. Department of Education. (2002). The No Child Left Behind Act of 2001. Retrieved February 1, 2009, from

http://www.ed.gov/policy/landing.jht $\mathrm{ml}$ ?src $=\mathrm{rt}$

Vacca, R.T., \& Vacca, J.L. (2002). Content area reading: Literacy and learning across the curriculum. Boston: Allyn and Bacon.

Vygotsky, L.S. (1978). Mind in society: The development of higher psychological processes. (M. Cole, V. J ohn-Seiner, S. Scribner, \& E. Souberman, Eds. \& Trans.). Cambridge, MA: Harvard University Press. (Original work published, 1934).

Alice J. Feret is an Associate Professor of Reading in the College of Education at East Carolina University. A graduate of Syracuse University and Virginia Tech, she has previously served professionally as an upper-elementary classroom teacher, reading specialist and K-5 language arts coordinator in New Jersey, Virginia, and Wisconsin public schools. Her research interests include various literacy issues, as they impact teacher education and retention.

Judith J. Smith is an Assistant Professor of Elementary Education in the College of Education at East Carolina University, Greenville, North Carolina. A graduate of East Carolina University, she has taught in public schools in three states and has served as director of a family literacy program. Her research interests include language/literacy, educational technology/21st century literacies, and teacherresearcher collaborative relationships. 